\title{
RASPOLAGANJE VODNIM DOBROM
}

Dr. sc. Jadranko Jug, sudac

Vrhovni sud Republike Hrvatske
UDK: 351.79

Ur.: 22. veljače 2016.

Pr.: 25. ožujka 2016.

Izvorni znanstveni rad

\begin{abstract}
Sažetak
U radu se obrađuju mogućnosti raspolaganja vodnim dobrom kao dobrom od interesa za Republiku Hrvatsku s aspekta raspolaganja pravom vlasništva kao stvarnim pravom i raspolaganja predmetom samog stvarnog prava. Ujedno se dijeli prikaz raspolaganja vodnim dobrom od raspolaganja javnim vodnim dobrom kao javnim dobrom u općoj uporabi. Uvodno se navodi pojam, određenje i pravni status vodnog dobra kao temelj analize mogućnosti raspolaganja ili ograničenja u raspolaganju vodnim dobrom, kao i osnovna obilježja raspolaganja stvarnim pravima općenito te raspolaganja dobrima od interesa za Republiku Hrvatsku i javnim dobrima u općoj uporabi.
\end{abstract}

Ključne riječi: vodno dobro, javno vodno dobro, dobra od interesa za Republiku Hrvatsku, javna dobra u općoj uporabi.

\section{UVOD}

Vodno dobro su nekretnine koje su posebnim zakonom proglašene kao dobro od interesa za Republiku Hrvatsku (dalje RH) i imaju njezinu posebnu zaštitu. ${ }^{1}$ Zakon o vlasništvu i drugim stvarnim pravima $^{2}$ određuje da su stvari za koje je na temelju Ustava $\mathrm{RH}^{3}$ posebnim zakonom određeno da su dobra od interesa za nju, pa imaju njezinu osobitu zaštitu, a nisu opća dobra, sposobne biti objektom prava vlasništva i drugih stvarnih prava. ${ }^{4}$ Jedina razlika između dobara od interesa za

1 V. čl. 8. st. 5. Zakona o vodama (Narodne novine, broj 153/09, 63/11, 130/11, 56/13 i 14/14 dalje ZV).

2 Narodne novine, broj 91/96, 68/98, 137/99, 22/00, 73/00, 129/00, 114/01, 79/06, 141/06, $146 / 08,38 / 09,153 / 09,143 / 12$ i 152/14 - dalje ZVDSP.

3 Narodne novine, broj 56/90, 135/97, 8/98, 113/08, 124/00, 28/01, 41/01, 55/01, 76/10, 85/10 i $5 / 14$.

4 V. čl. 4. st. 1. ZVDSP. Ustav RH u čl. 52. st. 1. određuje da su od interesa za RH i imaju njezinu osobitu zaštitu: more, morska obala i otoci, vode, zračni prostor, rudno blago i druga prirodna bogatstva, ali i zemljište, šume, biljni i životinjski svijet, drugi dijelovi prirode, nekretnine i stvari od osobitoga kulturnoga, povijesnoga, gospodarskog i ekološkog značenja, za koje je zakonom određeno da su od interesa za RH. 
RH i ostalih stvari u općem stvarnopravnom režimu odnosi se na posebnu pravnu regulativu glede uporabe, korištenja, raspolaganja i prava na njima. ${ }^{5}$ Stoga su dobra od interesa za RH sve one stvari koje su na temelju Ustava RH i posebnih zakona proglašene i stavljene u taj pravni status zbog svoje osobite kulturne, povijesne, gospodarske, ekološke važnosti, i zbog čega su podvrgnuti posebnom pravnom uređenju koje je različito u cijelosti ili u određenom dijelu od pravila općeg stvarnopravnog uređenja. Stvari koje su dobra od interesa za RH mogu biti u pravnom statusu općeg dobra i izvan vlasničkog režima, mogu biti u vlasništvu osoba javnog prava i u pravnom statusu javnog dobra ili u vlasništvu pravnih i fizičkih osoba. Kod općih dobara i javnih dobara u općoj uporabi ograničenja u odnosu na opće stvarnopravno uređenje proizlaze prije svega iz toga njihovog statusa, a ne iz činjenice da su ujedno proglašeni dobrima od interesa za RH, dok kod svih ostalih stvari, koje su proglašene dobrima od interesa za RH ograničenja u odnosu na opće stvarnopravno uređenje proizlaze iz te činjenice. ${ }^{6}$

Vodno dobro su nekretnine i zemljišne čestice u vlasničkopravnom režimu koje mogu biti vlasništvo bilo koje pravne ili fizičke osobe. Međutim, ako na njima pravo vlasništva ima $\mathrm{RH}$, nekretnine vodnog dobra su tada u pravnom statusu javnog dobra u općoj uporabi ${ }^{7}$ i podvrgnute su znatno većim ograničenjima u odnosu na mogućnost uporabe, korištenja i raspolaganja. Raspolaganje stvarnim pravom općenito znači da ovlaštenik tog prava može to pravo prenijeti na drugoga u cijelosti ili djelomično, da ga može opteretiti nekim ograničenim stvarnim pravom, da ga može ograničiti na neki drugi način i da se očitovanjem svoje volje može tog prava odreći ili učiniti da to pravo prestane. ${ }^{8}$ Raspolaganje predmetom stvarnog prava

5 U čl. 52. st. 2. Ustava RH određeno je da se zakonom određuje na koji način dobra od interesa za RH mogu upotrebljavati i koristiti njihovi vlasnici ili ovlaštenici prava na njima, a isto tako i naknadu za ograničenja kojima su podvrgnuti. Isto propisuje čl. 4. st. 2. ZVDSP-a.

6 U svezi s ograničenjem kojima su izloženi vlasnici dobara od interesa za RH Josipović, T. navodi: „Njihovim (vlasnicima dobara od interesa za RH, op. a.) vlasnicima nametnute su $i$ određene obveze glede njihova održavanja ili im je zabranjeno neko ponašanje kako se ne bi narušila određena svojstva stvari radi kojih su i proglašene dobrima od interesa za $R H$. V. Josipović, T., Posebni pravni režimi na nekretninama, Nekretnine u pravnom prometu, Inženjerski biro, Zagreb, 2003., str. 4.

7 V. čl. 11. ZV. Kao i kod općeg dobra, javna dobra u općoj uporabi namijenjena su za opću uporabu, a opća uporaba se određuje posebnim zakonima koji reguliraju pravni status i upravljanje određenim javnim dobrom u općoj uporabi, te u okviru ovlasti na upravljanje tijela pravnih osoba kojima je određena vrsta javnog dobra u općoj uporabi dana na upravljanje. ZVDSP u odnosu na javna dobra u općoj uporabi načelno određuje primjenu jednakih pravila kao za opća dobra, ako nije što drugo propisano zakonom. Međutim, ta načelna odredba ZVDSP-a nije značajna u odnosu na javna dobra u općoj uporabi u pravnom sustavu RH, jer je njihov pravni status, opća i posebna uporaba, gospodarsko korištenje, raspolaganje te upravljanje regulirano posebnim zakonima. Osnovna razlika između općih dobara i javnih dobara u općoj uporabi je da kod posebne uporabe ili gospodarskoga korištenja javnog dobra u općoj uporabi u odnosu na opća dobra, u tu svrhu nema mogućnosti stjecanja stvarnih prava, dok kod nekih javnih dobara takva mogućnost postoji.

8 V. Gavella, N. et al.; Stvarno pravo, Svezak 1., II. izmijenjeno i dopunjeno izd., Narodne novine, Zagreb, 2007., str. 130. 
razlikuje se od samog raspolaganja stvarnim pravom, te je zapravo poseban način izvršavanja sadržaja stvarnog prava i temelji se na ovlasti sadržanoj u konkretnom stvarnom pravu. ${ }^{9}$ Svaki pravni subjekt ovlašten je raspolagati svojim subjektivnim pravom koje je u prometu i za to mu nije potrebno nikakvo posebno ovlaštenje. Međutim, ako se stvar nalazi u posebnom pravnom režimu kao dobro od interesa za RH, odnosno kao javno dobro u općoj uporabi, pravo i sloboda raspolaganja stvarnim pravom kao i predmetom stvarnog prava ograničena je temeljem odredaba posebnog zakona.

Predmet ovoga rada je prikaz mogućnosti raspolaganja vodnim dobrom, odnosno javnim vodnim dobrom, i to u smislu raspolaganja subjektivnim pravom nositelja stvarnog prava te samim predmetom stvarnog prava, na toj posebnoj vrsti nekretnina od posebnog interesa za RH, ali i za sve njene građane. Uvodno će se navesti pojam, određenje i pravni status vodnog dobra kao temelj mogućnosti raspolaganja (neraspolaganja) vodnim dobrom.

\section{POJAM I ODREĐENJE VODNOG DOBRA}

ZV određuje da vodno dobro čine zemljišne čestice koje obuhvaćaju vodonosna i napuštena korita površinskih voda, uređeno inundacijsko područje ${ }^{10}$, neuređeno inundacijsko područje ${ }^{11}$, prostor na kojem je izvorište voda potreban za njegovu fizičku zaštitu ${ }^{12}$ te otoci koji su nastali ili nastanu u vodonosnom koritu. ${ }^{13}$ Nadalje, ZV popisuje najmanju i najveću površinu nekretnina vodnog dobra koje nije u vlasništvu RH, odnosno najmanju površinu nekretnina vodnog dobra koje je u vlasništvu RH, u slučaju vodnog dobra koje čini prostor potreban za fizičku zaštitu izvorišta voda. ${ }^{14} \mathrm{ZV}$ također propisuje da zemljišne čestice vodnog dobra

9 Ibid.

10 Uređeno inundacijsko područje čini zemljište između korita voda i vanjskog ruba pripadajućih mu regulacijskih i zaštitnih vodnih građevina, uključujući i pojas zemljišta potreban za njihovo redovito održavanje (v. čl. 109. st. 1. ZV).

11 Neuređeno inundacijsko područje čine zemljišta uz vodotoke, koje je planom upravljanja vodnim područjima ili dokumentom o uređenju prostora rezervirano za građenje regulacijskih i zaštitnih vodnih građevina, te prirodne i umjetne akumulacije i retencije u granicama utvrđenim planom upravljanja vodnim područjima ili prostornim planom (v. čl. 109. st. 2. ZV).

12 Pod izvorištem voda u smislu čl. 8. st. 1. toč. 4. ZV-a smatraju se sve vode namijenjene ljudskoj potrošnji koje osiguravaju u prosjeku više od $10 \mathrm{~m} 3$ vode na dan ili opskrbljuju više od 50 ljudi kao i sva vodna tijela rezervirana za te namjene u budućnosti (čl. 88. st. 1. ZV), a također izvorišta izdašnosti najmanje $10 \mathrm{~m} 3$ dnevno prirodne mineralne, termalne i prirodne izvorske vode.

13 V. čl. 8. st. 1. ZV.

14 V. čl. 8. st. 2. i 3. ZV. Prostor koji nije u vlasništvu RH ne može biti manji od 400 niti veći od 450 čhv oko izvorišta, tako da je izvorište u pravilu u središtu toga prostora. Prostor koji je u vlasništvu RH jedan je hektar oko izvorišta, tako da je izvorište u pravilu u središtu toga prostora ili iznimno manje površine ako je zemljište u vlasništvu RH na kojem je izvorište manje površine od jednog hektara. 
koje čine prostor na kojem je izvorište voda, moraju biti zasebne katastarske i zemljišnoknjižne čestice, te da se prije parcelacije osniva pravo služnosti prolaza i provoza do javne prometnice na teret svih nekretnina. ${ }^{15}$

Namjena vodnog dobra je da služi održavanju i poboljšanju vodnog režima, i to osobito za građenje i održavanje regulacijskih i zaštitnih vodnih građevina, održavanje korita i obala vodotoka, održavanje i uređenje inundacijskog područja, građenje i održavanje unutarnjih vodnih putova, provedbu obrane od poplava te korištenje i zaštitu izvorišta voda. ${ }^{16}$ Ministarstvo nadležno za vodno gospodarstvo u upravnom postupku utvrđuje pripadnost neke nekretnine vodnom dobru, uz prethodno pribavljeno mišljenje Hrvatskih voda, ${ }^{17}$ a rješenje koje donosi ministarstvo je konačno i ovršno i protiv njega nije dopuštena žalba već se može pokrenuti upravni spor. ${ }^{18}$ Rješenje ministarstva mora sadržavati oznaku nekretnine u skladu s podatcima iz zemljišne knjige i nalog nadležnom zemljišnoknjižnom sudu za njegovu provedbu, a dostavlja se i nadležnom državnom odvjetništvu. ${ }^{19}$ Vodno dobro može biti u vlasništvu fizičke ili pravne osobe, ali ako je u vlasništvu RH kao pravne osobe, tada se nalazi u pravnom statusu javnog vodnog dobra koje je javno dobro u općoj uporabi. Određenje javnog vodnog dobra znatno je složenije zbog odredbi ZV-a kojima određene nekretnine vodnog dobra ex lege postaju nekretnine javnog vodnog dobra.

\subsection{Pojam i određenje javnog vodnog dobra}

Javno vodno dobro čine nekretnine koje su vodno dobro ${ }^{20}$, ali su u vlasništvu RH. Dakle, javno vodno dobro razlikuje se od vodnog dobra jedino po tome što su takve nekretnine u vlasništvu države, dok vodno dobro može biti u vlasništvu bilo koje pravne ili fizičke osobe. Javno vodno dobro je primarno javno dobro u općoj uporabi i u vlasništvu RH, ali može biti i u pravnom statusu javnog dobra u javnoj uporabi u vlasništvu RH, kada se radi o vodnim građevinama izgrađenim na javnom vodnom dobru i ako je tako određeno aktom vlasnika. ${ }^{21}$ Ukoliko je na zemljišnoj čestici koja je u pravnom statusu javnoga vodnog dobra izgrađena vodna građevina, ${ }^{22}$ tada se sukladno načelu jedinstva nekretnine radi o jedinstvenoj

15 V. čl. 8. st. 4. ZV. Takvo zakonsko rješenje potpuno je logično jer do te vrste vodnog dobra mora biti omogućen prilaz vozilima i na drugi način u svrhu korištenja i zaštite izvorišta voda što je jadna od namjena vodnog dobra.

16 V. čl. 9. ZV.

17 V. čl. 10. st. 1. ZV.

18 V. čl. 10. st. 4. i $6 . \mathrm{ZV}$.

19 V. čl. 10. st. 4. i 6. ZV. Rješenje se dostavlja nadležnom državnom odvjetništvu radi stavljanja prijedloga za uknjižbu prava prvokupa u korist RH (v . čl. 18. st. 3. i čl. 19. ZV).

20 V. supra bilj. 12

21 V. čl. 11. st. 4. i čl. 14. st. 2. ZV.

22 Namjena, vrste, pravni status i ostala obilježja vodnih građevina određeni su u čl. 21. - 30. $\mathrm{ZV}$-a. 
nekretnini u pravnom statusu javnoga vodnog dobra i u vlasništvu RH. ${ }^{23}$ Iznimka od tog pravila odnosi se na vodne građevine koje su izgrađene na temelju prava građenja ili prava služnosti, u kojem slučaju izgrađene vodne građevine na temelju tih prava, i dok ona traju, nisu dio javnog vodnog dobra. ${ }^{24}$ Kada je na javnome vodnom dobru izgrađena vodna građevina kao pripadnost javnome vodnom dobru, RH kao vlasnik određenoga javnoga vodnog dobra može odrediti da je takvo javno vodno dobro u javnoj, a ne u općoj uporabi. ZV sadrži i jednu odredbu koja je u koliziji s odredbama Zakona o cestama ${ }^{25}$, a odnosi se na preklapanje javne ceste i javnoga vodnog dobra. Tako ZV određuje da se građenjem cestovnih i željezničkih prometnica na javnom vodnom dobru ne mijenja pravni status javnoga vodnog dobra, ${ }^{26}$ dok $\mathrm{ZC}^{27}$ u tom slučaju predviđa mogućnost ukidanja statusa javnoga vodnog dobra. Mišljenja sam da u takvoj situaciji treba tumačiti te odredbe na način da sukladno ZC-u uvijek postoji mogućnost ukidanja statusa javnog vodnog dobra kada je to potrebno u svrhu građenja, rekonstrukcije i održavanja javne ceste, odnosno da se ne mijenja izgradnjom javne ceste na javnom vodnom dobru taj pravni status nekretnine, osim ako se ne odluči primijeniti odredba $\mathrm{ZC}{ }^{28}$

ZV kao prvi kriterij za utvrđenje nekretnina u pravnom statusu javnoga vodnog dobra navodi da se mora raditi o nekretninama ili zemljišnim česticama koje su vodno dobro. Takva odredba ZV-a nije sporna jer je potpuno logično da pravni status javnoga vodnog dobra primarno proizlazi iz vrste i namjene nekretnina koje taksativno navodi ZV. ${ }^{29}$ Slijedom toga, sve nekretnine koje se stječu temeljem izvlaštenja ili pravnog posla u korist $\mathrm{RH}$, a u naravi se radi o vodnom dobru, nalaze se u pravnom statusu javnoga vodnog dobra. ${ }^{30}$ Problem se javlja kod odredbe $\mathrm{ZV}$-a kojom se ex lege određuje da su određene nekretnine, koje su u naravi vodno dobro, postale na dan stupanja na snagu Zakona o vodama iz $1995 .{ }^{31}$ godine javno vodno dobro. ${ }^{32}$ Mjerilo za utvrđenje javnoga vodnog dobra po toj je osnovi određeni pravni status nekretnine na dan stupanja na snagu ZV/95, a koji se može procjenjivati u materijalnopravnom i u formalnopravnom smislu.

23 V. čl. 14. st. 1. ZV.

24 Ibid.

25 Narodne novine, broj 84/11, 22/13, 54/13, 148/13 i 92/14 - dalje ZC.

26 V. čl. 14. st. 3. ZV.

27 V. čl. 44. ZC.

28 Ibid.

29 V. čl. 8. st. 1. ZV.

30 V. čl. 11. st. 3. ZV.

31 Narodne novine, broj 107/95 i 150/05 - dalje ZV/95.

32 U čl. 11. st. 1. ZV-a određeno je da javno vodno dobro čine zemljišne čestice iz članka 8. ZV-a koje su do dana stupanja na snagu ZV/95 bile temeljem zakona ili temeljem bilo koje druge pravne osnove: opće dobro, javno dobro, javno vodno dobro, vodno dobro, javno dobro - vode, državno vlasništvo, vlasništvo jedinice lokalne samouprave, društveno vlasništvo bez obzira tko je bio nositelj prava korištenja, upravljanja ili raspolaganja, odnosno koje su u zemljišnoj knjizi bile upisane kao: javno dobro, javno vodno dobro, vodno dobro, državno vlasništvo, vlasništvo jedinice lokalne samouprave, društveno vlasništvo s naznakom ili bez naznake nositelja prava korištenja, upravljanja ili raspolaganja, općenarodna imovina, opće dobro i sl. 
Može se prihvatiti da su nekretnine vodnog dobra, koje su temeljem zakona ili neke druge pravne osnove bile na navedeni datum opće dobro ili javno dobro, društveno vlasništvo te vlasništvo $\mathrm{RH}$, postale temeljem zakona javno vodno dobro u vlasništvu RH i u pravnom statusu javnog dobra u općoj uporabi. Međutim, smatramo neprihvatljivim da su nekretnine vodnog dobra u vlasništvu JLS-a također postale javno vodno dobro u vlasništvu RH, jer bi se u tom slučaju radilo o oduzimanju prava vlasništva nekretnine određenoj pravnoj osobi javnog prava bez naknade i provođenja postupka izvlaštenja. ${ }^{33}$ Također je neprihvatljivo da se prelazak određenih zemljišnih čestica vodnog dobra u pravni status javnoga vodnog dobra veže uz formalni upis u zemljišnim knjigama na dan stupanja na snagu ZV/95, a to posebno iz razloga nesređenosti faktičnoga i zemljišnoknjižnog stanja. ${ }^{34}$ Nije poznato da bi netko pokrenuo postupak ocjene ustavnosti odredbe čl. 11. st. 1. ZV-a, slijedom čega je upitno bi li stvarni vlasnici vodnog dobra, koje je temeljem takve odredbe ZV-a postalo javno vodno dobro, mogli ostvariti zaštitu svojeg prava vlasništva u parnici ili u zemljišnoknjižnom postupku povodom uknjižbe javnoga vodnog dobra. ZV predviđa i predmnjevu da su sve nekretnine vodnog dobra, a koje na dan stupanja na snagu ZV-a nisu bile upisane u zemljišnoj knjizi, ili su bile upisane bez naznake njihova vlasnika, smatraju do dokaza suprotnog javnim vodnim dobrom..$^{35}$ Ta odredba $\mathrm{ZV}$-a također je upitna s ustavnopravnog motrišta jer prebacuje teret dokaza da je određena nekretnina javno vodno dobro s RH na one koji tvrde da se radi o vodnom dobru u vlasništvu određene fizičke ili pravne osobe.

ZV predviđa da nadležno ministarstvo za vodno gospodarstvo ima ovlast u slučaju dvojbe ili spora utvrđivati je li neka zemljišna čestica vodnog dobra po sili zakona postala javno vodno dobro temeljem čl. 11. st. 1. i 2. ZV-a. ${ }^{36}$ Zakonodavac je predvidio upravni postupak za utvrđenje pripadnosti nekretnine vodnom dobru, a također za utvrđenje ex lege stečenog statusa javnog vodnog dobra na nekretninama vodnog dobra. Sudska zaštita predviđena je pokretanjem upravnog spora protiv rješenja ministarstva, a koji se pokreće direktno protiv rješenja ministarstva jer žalba nije dopuštena.

Zakonom o izmjenama i dopunama ZV/95 ${ }^{37}$ u prijelaznim odredbama bila je predviđena mogućnost uknjižbe RH na svim nekretninama koje su u statusu javnoga vodnog dobra, a koje su bile u posjedu Hrvatskih voda najmanje deset godina do dana stupanja na snagu ZID ZV/95. ${ }^{38}$ Ova odredba odnosila se i na uknjižbu vodnih

33 Ustav RH u čl. 50. st. 1. određuje da je zakonom moguće u interesu RH ograničiti ili oduzeti vlasništvo, uz naknadu tržišne vrijednosti.

34 Tako je moguće da je određena zemljišna čestica vodnog dobra temeljem pretvorbe određenoga društvenog poduzeća prešla u imovinu i vlasništvo novoosnovanoga trgovačkog društva, ali je u zemljišnoj knjizi ostala upisana kao društveno vlasništvo s pravom korištenja prednika društvenog poduzeća, a prema odredbi čl. 11. st. 1. ZV-a postala bi ex lege javno vodno dobro i vlasništvo RH.

35 V. čl. 11. st. 2. ZV.

36 V. čl. 10. st. 2. ZV.

37 Narodne novine, broj 150/05 - dalje ZID ZV/95.

38 V. čl. 123. st. 1. ZID ZV/95. 
građevina, s tim što se vodne građevine za melioracijsku odvodnju uknjižuju kao vlasništvo županije. ${ }^{39}$ Temelj za uknjižbu bio je katastarski posjedovni list i potvrda Hrvatskih voda da se radi o nekretninama u pravnom režimu javnoga vodnog dobra i/ili vodnim građevinama. Kod toga smatramo da je jedino povijesni posjedovni list mogao biti dokaz o posjedovanju nekretnine tijekom razdoblja od 10 godina, a isto tako smatramo da je ispravno trebalo biti navedeno kako se radi o nekretnini u pravnom režimu vodnog dobra, a ne javnoga vodnog dobra. Naime, status vodnog dobra odnosi se prije svega na određene vrste nekretnine u naravi, dok je status javnoga vodnog dobra u biti pravni status nekretnina koje su u naravi vodno dobro.

Osoba koja je do tada bila uknjižena kao vlasnik, ovlaštena je bila podnijeti brisovnu tužbu prema pravilima zemljišnoknjižnog prava ${ }^{40}$ u prekluzivnom roku od 6 mjeseci od dana dostave rješenja suda o uknjižbi prava vlasništva $R H$, odnosno prava vlasništva županije na vodnoj građevini. Vidljivo je da je ZID ZV/95, kao lex specialis, na posve drugačiji način regulirao predmnjevu o nositelju prava vlasništva na određenoj nekretnini, za razliku od ZZK-a, gdje je opća pretpostavka da je vlasnik nekretnine osoba koja je kao takva upisana u zemljišnoj knjizi, a tko tvrdi suprotno to treba i dokazati. ${ }^{41}$ Odredba ZID ZV/95 o svojevrsnom stjecanju pravnog statusa javnoga vodnog dobra temeljem dosjelosti i temeljem dokaza da se radi o vodnom dobru i posjedu Hrvatskih voda, a sve to u zemljišnoknjižnom postupku, također je u suprotnosti s odredbom čl. 50. st. 1. Ustava RH. Osim toga, u zemljišnoknjižnom postupku ne mogu se utvrđivati sporne činjenice, ${ }^{42}$ a koje se odnose na pretpostavku desetogodišnjeg posjeda, slijedom čega je i ta odredba ZID ZV/95 u svezi s utvrđenjem javnoga vodnog dobra bila dvojbena.

ZV sadrži sličnu odredbu kao i ZV/95 o svojevrsnom stjecanju pravnog statusa javnog vodnog dobra i uknjižbi temeljem dosjelosti na nekretninama vodnog dobra, ali s nekim bitnim razlikama, posebno u svezi s mogućnosti pravne zaštite upisanih vlasnika takvih nekretnina vodnog dobra. ${ }^{43}$ Tako je i dalje predviđeno da će sudovi provesti uknjižbu javnog vodnog dobra u vlasništvu RH na svim nekretninama koje su vodno dobro, ${ }^{44}$ a koje su u posjedu Hrvatskih voda najmanje 10 godina do dana stupanja na snagu $\mathrm{ZV}$-a, te da prijedlog za uknjižbu podnosi nadležno državno odvjetništvo, a dokaz posjeda od 10 godina se dokazuje potvrdom tijela nadležnog za katastar te pripadnost zemljišne čestice vodnom dobru potvrdom Hrvatskih voda. Međutim, u ZV-u su izostale odredbe ZV/95 o tome da se takvo stjecanje pravnog statusa javnog vodnog dobra odnosi na vodne građevine, kao i odredbe o pravu bivših vlasnika na brisovnu tužbu u roku 6 mjeseci od zaprimanja rješenja kojim se odobrava uknjižba. Dakle, prema ZV-a se takva uknjižba može provesti bez obzira

39 V. čl. 123. st. 3. ZID ZV/95.

40 V. čl. 123. st. 2. ZID ZV/95 i čl. 129. Zakona o zemljišnim knjigama (Narodne novine, broj 91/96, 68/98, 137/99, 114/01, 100/04107/07, 152/08126/10, 55/13 i 60/13 - dalje ZZK).

41 V. čl. 8. st. 2. ZZK.

42 V. čl. 92. i 108. ZZK.

43 V. čl. 254. st. 1. i 2. ZV.

44 Sada je zakonodavac pravilno razlučio pojam vodnog dobra u naravi od pravnog statusa javnog vodnog dobra koji se stječe upisom te vrste nekretnina u vlasništvo RH. 
na upisano pravo vlasništva druge osobe i bez mogućnosti podnošenja brisovne tužbe. Smatram da takve odredbe ZV-a ne sprječavaju osobu protiv koje je izvršena uknjižba javnog vodnog dobra u vlasništvu RH temeljem svojevrsne dosjelosti Hrvatskih voda, da pokrene parnicu u kojoj će pobijati pretpostavke za stjecanje pravnog statusa javnog vodnog dobra ili tvrditi da se uopće ne radi o nekretnini vodnog dobra.

Ukupno je utvrđenje nekretnina u pravnom statusu javnoga vodnog dobra s obzirom na odredbe ZV-a i ZID ZV/95 znatno otežano, a vrlo često nije provedivo u zemljišnoknjižnom postupku kako je to zakonodavac predvidio.

\section{OPĆENITO O RASPOLAGANJU STVARNIM PRAVIMA I PREDMETOM STVARNIH PRAVA}

Raspolaganje stvarnim pravom može se odnositi na raspolaganje stvarnim pravom kao subjektivnim pravom, a može se odnositi i na raspolaganje predmetom stvarnog prava. Raspolaganje stvarnim pravom kao subjektivnim pravom podrazumijeva prijenos tog prava na drugu osobu u cijelosti ili djelomično ${ }^{45}$, opterećenje tog prava nekim ograničenim stvarnim pravom ${ }^{46}$, ograničenje stvarnog prava u nekom drugom pogledu ${ }^{47}$ te mogućnost odricanja od nekog stvarnog prava ${ }^{48}$. $\mathrm{Za}$ valjanost raspolaganja trebaju biti ispunjene opće i posebne pretpostavke. Opće pretpostavke su sposobnost predmeta biti predmetom raspolaganja, sposobnost stjecatelja da stekne određeno stvarno pravo te valjana pravna osnova stjecanja. Posebne pretpostavke ovise o vrsti pravne osnove raspolaganja.

Kod raspolaganja predmetom stvarnog prava radi se zapravo o izvršavanju sadržaja određenog stvarnog prava, a ne o raspolaganju subjektivnim pravom. Raspolaganje predmetom stvarnog prava moguće je u okviru ovlasti koje proizlaze iz stvarnog prava. Jedino pravo vlasništva u pravilu ovlašćuje nositelja tog prava na bilo kakvo raspolaganje sa stvari, ${ }^{49}$ dok ograničena stvarna prava sadrže ujedno i ograničenu ovlast raspolaganja sa samom stvari koja je predmet ograničenog stvarnog prava $^{50}$. Raspolaganje predmetom stvarnog prava također možemo podijeliti na faktično raspolaganje ${ }^{51}$ i pravno raspolaganje ${ }^{52}$. Može se zaključiti da je koji puta vrlo teško razlikovati raspolaganje stvarnim pravom od raspolaganja

45 Prijenos stvarnog prava podrazumijeva prestanak tog prava jedne osobe i stjecanje istog prava druge osobe. Prijenos stvarnog prava može biti u cijelosti ili djelomično (npr. prijenos prava vlasništva u cijelosti ili samo određenog suvlasničkog dijela).

46 Npr. opterećenje prava vlasništva nekretnine osnivanjem prava služnosti ili prava građenja na toj nekretnini ili opterećenje založnog prava osnivanjem podzaložnog prava.

47 Npr. ograničenje raspolaganja pravom vlasništva pravom prvokupa neke osobe.

48 Npr. očitovanjem volje izazvati prestanak stvarnog prava.

49 Upravo u slučaju javnog vodnog dobra u vlasništvu RH dolazi do znatne nemogućnosti raspolaganja stvarnim pravom i samim predmetom stvarnog prava (čl. 11. st. 5. i čl. 16. ZV).

50 Npr. nositelj prava plodouživanja može stvar dati u zakup, ali je ne može otuđiti.

51 Faktično raspolaganje odnosi se na promjenu oblika, sadržaja, mjesta gdje se stvar nalazi itd.

52 Pravno raspolaganje je, primjerice, davanje stvari u posjed. 
predmetom stvarnog prava, jer vrlo često raspolaganje subjektivnim pravom znači ujedno i raspolaganje samim predmetom tog subjektivnog prava. ${ }^{53}$

\subsection{Općenito o raspolaganju dobrima od interesa za $\mathrm{RH}$}

Dobra od interesa za RH su dobra koja na temelju Ustava RH i zakona uživaju osobitu zaštitu $\mathrm{RH}$, a iz odredbe Ustava $\mathrm{RH}^{54}$ nedvojbeno proizlazi da su dobra od interesa za RH more, vode, zračni prostor, morska obala, otoci i rudno blago, dok u odnosu na ostale nekretnine i stvari samo ako je zakonom određeno da su od interesa za RH. Vidljivo je da su u samom Ustavu RH kao dobra od interesa za Republiku Hrvatsku proglašena upravo opća dobra kao što su zrak, voda u rijekama, jezerima i moru i morska obala, te otoci ${ }^{55}$ i rudno blago ${ }^{56}$ koji su u režimu vlasništva. Sve ostale nekretnine i pokretnine mogu postati dobra od interesa za RH, ako su kao takvi proglašeni posebnim zakonom. Pojam dobro od interesa za RH znatno je širi od pojma općeg dobra ili javnog dobra te u statusu dobara od interesa za RH mogu biti opća dobra, javna dobra u općoj uporabi, javna dobra u javnoj uporabi, kao i ostale stvari u općem stvarnopravnom režimu.

ZVDSP određuje da su stvari za koje je na temelju Ustava RH posebnim zakonom određeno da su dobra od interesa za nju pa imaju njezinu osobitu zaštitu, a nisu opća dobra, sposobne biti objektom prava vlasništva i drugih stvarnih prava. ${ }^{57}$ Jedina razlika između dobara od interesa za RH i ostalih stvari u općem stvarnopravnom režimu odnosi se na posebnu pravnu regulativu glede uporabe, korištenja i prava na njima. ${ }^{58}$ Ograničenja i obveze koje mogu biti nametnute vlasnicima dobara od interesa za RH mogu se primjerice odnositi na obvezu određenog održavanja stvari, ograničenja u svezi s raspolaganjem stvarju, ${ }^{59}$ dužnost dopustiti uporabu stvari za određene namjene i sl. Ograničenja u raspolaganju i obveze vlasnika dobra od interesa za RH ovise o vrsti i namjeni dobra od interesa za RH kao i cilju koji se želi postići stavljanjem neke stvari u taj poseban pravni status. Odredbe ZVDSP-a, kao glavni pravni izvor općega stvarnopravnog uređenja, u tim se slučajevima primjenjuju samo supsidijarno, ako i ukoliko posebnim zakonom za pojedine stvari nije drukčije određeno. ${ }^{60}$

53 Tako se kod prodaje neke stvari radi o prijenosu prava vlasništva određene stvari na drugu osobu, ali se istovremeno raspolaže i samom stvarju kao predmetom prava vlasništva.

54 V. supra bilj. 5

55 V. čl. 1. st. 1. Zakona o otocima (Narodne novine, broj 34/99, 149/99, 32/02 i 33/06 - dalje $\mathrm{ZO})$.

56 V. čl. 3. Zakona o rudarstvu (Narodne novine, broj 75/09 i 49/11 - dalje ZR).

57 V. čl. 4. st. 1. ZVDSP.

58 U čl. 52. st. 2. Ustava RH određeno je da se zakonom određuje na koji način se dobra od interesa za RH mogu upotrebljavati i koristiti od strane njihovih vlasnika ili ovlaštenika prava na njima, a isto tako i naknada za ograničenja kojima su podvrgnuti. Isto propisuje čl. 4. st. 2. ZVDSP.

59 Najčešće se radi o pravu prvokupa RH i jedinica područne (regionalne) i lokalne samouprave.

60 Josipović, T., Posebni pravni režimi na nekretninama, op. cit., str. 4. 


\subsection{Općenito o raspolaganju javnim dobrima и općoj uporabi}

Prema ZVDSP-a javna dobra u općoj uporabi bile bi stvari koje su u vlasništvu RH i drugih osoba javnog prava koje su namijenjene za opću uporabu (uporabu svih). ${ }^{61}$ Stoga je opća uporaba obilježje koje određeno javno dobro prema kriteriju namjene ili uporabe svrstava $u$ javna dobra u općoj uporabi. Namjenu javnog dobra u općoj uporabi u pravnom sustavu RH određuje zakon, ${ }^{62}$ iako opća odredba ZVDSP-a predviđa mogućnost da to učini i državno tijelo koje je na to ovlašteno zakonom. ${ }^{63} \mathrm{U}$ pravnom sustavu RH samo nekretnine su u pravnom statusu javnog dobra u općoj uporabi ${ }^{64}$ što je inače i pravilo, s obzirom na to da opća uporaba neke pokretne stvari u vlasništvu osoba javnog prava nije uobičajena. ${ }^{65}$

Kod javnih dobara u općoj uporabi način ostvarenja opće uporabe određuje tijelo ili ustanova kojoj su javna dobra u općoj uporabi dana na upravljanje, odnosno tijelo nadležno za određivanje namjene koje njima neposredno upravlja. Tako način ostvarenja opće uporabe javnih cesta određuju pravne osobe koje su osnovane za upravljanje javnim cestama, ${ }^{66}$ način ostvarenja opće uporabe javnoga vodnog dobra pravna osoba osnovana za upravljanje vodama $i$ javnim vodnim dobrom, ${ }^{67}$ a način ostvarenja opće uporabe željezničke infrastrukture određuje pravna osoba koja upravlja tom vrstom javnog dobra u općoj uporabi ${ }^{68}$ Dakle, opća uporaba javnih dobara ne može se ostvarivati prema nahođenju i potrebama svakog pojedinca, već se određuje posebnim zakonima koji reguliraju pravni status i upravljanje određenim javnim dobrom u općoj uporabi, te u okviru ovlasti na upravljanje tijela pravnih osoba kojima je određena vrsta javnog dobra u općoj uporabi dana na upravljanje.

61 V. čl. 35. st. 4. ZVDSP. O javnim dobrima u općoj uporabi v. više: Jug, J.; Opća dobra i javna dobra u općoj uporabi - dvojbe i prijedlozi, Nekretnine u vlasništvu Republike Hrvatske i opća dobra, Inženjerski biro, Zagreb, 2007.

62 Tako je u ZV-u određeno da je javno vodno dobro u vlasništvu RH i ujedno javno dobro u općoj uporabi (čl. 11. st. 4. ZV), u ZC-u da su javne ceste i nerazvrstane ceste javno dobro u općoj uporabi i u vlasništvu RH, odnosno JLS (čl. 3. st. 1. i čl. 101. st. 1. ZC), u Zakonu o željeznici (Narodne novine, broj 94/13 i 148/13 - dalje ZŽ) da je željeznička infrastruktura javno dobro u općoj uporabi i u vlasništvu RH (čl. 11. st. 1. ZŽ).

63 V. čl. 35. st. 3. ZVDSP.

64 V. supra bilj. 62.

65 To međutim nije isključeno, jer ima primjera u nekim europskim gradovima (Nizozemska) da se i pokretne stvari u vlasništvu gradova određuju za uporabu svih u skladu s načinom koji određuje tijelo kojemu su takve stvari dane na upravljanje (uporaba bicikla koji se nalaze na javnim površinama i dostupni su svim građanima radi prijevoza).

66 To su Hrvatske autoceste d.o.o. za autoceste, Hrvatske ceste d.o.o. za državne ceste, Županijske uprave za ceste za županijske i lokalne ceste (V. čl. 81. - 83. ZC).

67 Javnim vodnim dobrom upravljaju Hrvatske vode, osim ako u ZV-u nije drugačije određeno (čl. 15. ZV). Korištenje javnoga vodnog dobra za odmor i rekreaciju, u koju svrhu svatko pod jednakim uvjetima može koristiti javno vodno dobro, određuje jedinica lokalne samouprave uz prethodnu suglasnost Hrvatskih voda (čl. 17. ZV).

68 Željezničkom infrastrukturom upravlja upravitelj željezničke infrastrukture kojeg odredi vlasnik željezničke infrastrukture ili kojoj vlasnik željezničke infrastrukture dodijeli koncesiju (V. čl. 15. ZŽ). 
Sve nekretnine koje su u pravnom sustavu RH u pravnom statusu javnog dobra u općoj uporabi mogu se osim opće uporabe dati na posebnu uporabu ili gospodarsko korištenje. U pravilu je to putem koncesija, ali isto tako i temeljem nekih drugih pravnih poslova. Tako se dio javnoga vodnog dobra može dati u zakup, najam, ili se može osnovati pravo služnosti ili pravo građenja radi ostvarenja osobnih ili gospodarskih potreba, pod uvjetom da to ne utječe na održavanje vodnog režima. ${ }^{69}$ Cestovno zemljište, kao dio javne ceste, može se dati na korištenje radi gradnje pratećih uslužnih objekata i obavljanja uslužnih djelatnosti, a može se dati i koncesija u svrhu građenja, upravljanja i gospodarskoga korištenja javne ceste. $^{70}$ Koncesija se također može dati za izgradnju nove i upravljanje postojećom željezničkom infrastrukturom. ${ }^{71}$ Sve navedeno u biti predstavlja raspolaganje određenom vrstom javnog dobra u općoj uporabi, bilo kao raspolaganje stvarnim pravom ili predmetom stvarnog prava.

Javna dobra u općoj uporabi u pravnom sustavu RH, kao i sve stvari u vlasništvu RH, podvrgnuta su načelno djelovanju općih normi stvarnog prava iz ZVDSP-a. Međutim, posebnim zakonima koji pravno reguliraju određeno javno dobro u općoj uporabi propisana su izuzeća i ograničenja od djelovanja općih odredbi ZVDSP-a. Javno vodno dobro, javne i nerazvrstane ceste te željeznička infrastruktura su neotuđivi iz vlasništva RH, odnosno JLS-a, i na njima se ne mogu u pravilu stjecati druga stvarna prava ${ }^{72}$, odnosno nekretnine koje čine navedena javna dobra u općoj uporabi mogu biti u pravnom prometu tek nakon ukidanja tog statusa prema izričito propisanom postupku. ${ }^{73}$ ZVDSP u odnosu na javna dobra $u$ općoj uporabi načelno određuje primjenu jednakih pravila kao za opća dobra, ako nije što drugo propisano zakonom. ${ }^{74}$ Međutim, ta načelna odredba ZVDSP-a nije značajna u odnosu na javna dobra u općoj uporabi u pravnom sustavu RH, jer je njihov pravni status, opća i posebna uporaba, gospodarsko korištenje, upravljanje i regulirano posebnim zakonima.

69 V. čl. 16. ZV.

70 V. čl. 73. i 75. ZC.

71 V. čl. 59. ZŽ-a.

72 U čl. 11. st. 5. ZV-a određeno je da je javno vodno dobro neotuđivo, dok je u čl. 11. st. 6. ZV-a određeno da neka druga osoba ne može dosjelošću ili na drugi način steći pravo vlasništva ili neko drugo stvarno pravo, osim prava služnosti i prava građenja u smislu čl. 16 . ZV-a. U čl. 3. st. 2. ZC-a određeno je da se javne ceste ne mogu otuđiti iz vlasništva $\mathrm{RH}$, niti se na njima mogu stjecati stvarna prava, osim prava služnosti i prava građenja u smislu čl. 3. st. 3. ZC. U ZŽ-a nema izričite odredbe o tome da bi ta vrsta javnog dobra u općoj uporabi bila neotuđiva iz vlasništva RH, ali se to može zaključiti iz odredbe čl. 13. ZŽ-a koji propisuje pretpostavke za oduzimanje statusa javnog dobra u općoj uporabi željezničkoj infrastrukturi, nakon čega se nekretninom koja više nije dio željezničke infrastrukture i javnog dobra u općoj uporabi može slobodno raspolagati.

73 V. čl. 12. ZV, čl. 5. i 103. ZC i čl. 13. ZŽ.

74 V. čl. 35. st. 4. ZVDSP. To bi značilo da se na javna dobra u općoj uporabi, u slučaju izostanka pravila u posebnim zakonima, primjenjuju odredbe ZVDSP-a koja reguliraju upravljanje općim dobrima (čl. 3. st. 3.), iznimku od načela jedinstvenosti nekretnine u slučaju izgradnje zgrade ili građevine na općem dobru temeljem koncesije (čl. 3. st. 4. i čl. 9. st. 4.). 


\section{RASPOLAGANJE VODNIM DOBROM I JAVNIM VODNIM DOBROM}

Mogućnosti, načini i ograničenja raspolaganja vodnim dobrom ovise o tome da li je vodno dobro u vlasništvu RH ili drugih pravnih i fizičkih osoba. U prvom slučaju radi se o daleko većim ograničenjima u mogućnosti raspolaganja samim pravom vlasništva, ali isto tako i raspolaganjem vodnim dobrom kao predmetom prava vlasništva. Činjenica da je određena nekretnina vodnog dobra u vlasništvu $\mathrm{RH}$, bez obzira na način stjecanja prava vlasništva $\mathrm{RH}^{75}$, zemljišnu česticu tog vodnog dobra ZV stavlja u pravni status javnog vodnog dobra kao dobra u općoj uporabi, a time je mogućnost raspolaganja pravom vlasništva kao subjektivnim pravom i raspolaganje predmetom tog stvarnog prava bitna drugačija nego kod nekretnina vodnog dobra koje nisu u vlasništvu RH.

\subsection{Raspolaganje vodnim dobrom}

Vlasnici zemljišnih čestica vodnog dobra koje su izvan sustava javnog vodnog dobra, mogu raspolagati svojim stvarnim pravom gotovo isto kao i vlasnici bilo koje druge nekretnine koja je u općem stvarnopravnom režimu. Jedina i osnovna razlika odnosi se na otuđenje ili prijenos nekretnine vodnog dobra, odnosno prava vlasništva, u kojem slučaju RH ima pravo prvokupa. ${ }^{76}$ Pravo prvokupa RH ostvaruje se na način da je vlasnik nekretnine vodnog dobra koju namjerava prodati, dužan prvotno podnijeti ponudu Hrvatskim vodama i to po tržnim cijenama u mjestu prodaje. ${ }^{77}$ Nakon zaprimanja ponude, Hrvatske vode dužne su u daljnjem roku od 30 dana ponudu sa svojim mišljenjem dostaviti nadležnom ministarstvu za vodno gospodarstvo i tijelu $\mathrm{RH}$ nadležnom za upravljanje imovinom $\mathrm{RH}^{78}$, a koji su u daljnjem roku od 60 dana dužni obavijestiti Hrvatske vode i podnositelja ponude o prihvaćanju i uvjetima prihvaćanja ili odbijanja ponude. ${ }^{79}$ Ako se prihvati ponuda, ugovor u ime i za račun RH sklapaju Hrvatske vode, uz prethodno mišljenje nadležnog županijskog državnog odvjetništva. ${ }^{80}$ Ako RH ne iskoristi pravo prvokupa, vlasnik je slobodan prodati nekretninu vodnog dobra po svom nahođenju. ${ }^{81} \mathrm{U}$ svrhu publiciteta $\mathrm{ZV}$ određuje da se nekretnine vodnog dobra u

75 Nije bitno je li konkretna zemljišna čestica stečena kupnjom, izvlaštenjem ili je ex lege postala vlasništvo RH (čl. 11.).

76 V. čl. 19. st. 1. ZV.

77 Nije jasno što je zakonodavac podrazumijevao pod time da je vlasnik dužan podnijeti ponudu po „tržnim cijenama u mjestu prodaje“. Proizlazilo bi da vlasnik ne može navesti niti višu, ali niti nižu cijenu od tržne. Posebno smatramo da je neprihvatljivo da vlasnik ne može navesti nižu cijenu od tržne, jer bi RH imala jedino interes da netko ne traži nerealno visoku cijenu iznad tržne cijene.

78 V. čl. 19. st. 3. ZV.

79 V. čl. 19. st. 4. ZV.

80 V. čl. 19. st. 5. ZV.

81 V. čl. 19. st. 6. ZV. 
zemljišnoj knjizi uknjižuju na način da se u posjedovnici (list A) navede da se radi o vodnom dobru, a u tererovnici (list C) uknjižit će se pravo prvokupa u korist $\mathrm{RH}^{8}{ }^{82}$

U odnosu na opterećenje prava vlasništva vodnog dobra nekim ograničenim stvarnim pravom ili u nekom drugom pogledu, nema razlike u raspolaganju vodnim dobrom u odnosu na bilo koju drugu nekretninu. Kod raspolaganja vodnim dobrom kao predmetom stvarnog prava, ZV propisuje da su vlasnici dužni dopustiti njihovo privremeno korištenje u svrhu održavanja i poboljšanja vodnog režima. ${ }^{83} \mathrm{ZV}$ propisuje i niz drugih ograničenja prava vlasnika i posjednika nekretnina vodnog dobra, koja u svojoj biti predstavljaju ograničenje ovlasti raspolaganja predmetom prava vlasništva.$^{84}$ Odstupanja od zabrana i ograničenja raspolaganja vodnim dobrom kao predmetom stvarnog prava moguća su samo uz suglasnost Hrvatskih voda pod uvjetom da ne dolazi do ugrožavanja stabilnosti i sigurnosti vodnih građevina, da ne dolazi do pogoršanja postojećeg vodnog režima, i ako to nije protivno uvjetima korištenja vodnog dobra utvrđenim u ZV. ${ }^{85}$ Može se zaključiti da je kod raspolaganja pravom vlasništva vodnog dobra kao stvarnim pravom jedino ograničenje u pravu prvokupa $\mathrm{RH}$, dok kod raspolaganja vodnim dobrom kao

82 V. čl. 18. st. 3. ZV,

83 To osobito za građenje i održavanje regulacijskih i zaštitnih vodnih građevina, održavanje korita i obala vodotoka, održavanje i uređenje inundacijskog područja, građenje i održavanje unutarnjih vodnih putova, provedbu obrane od poplava te korištenje i zaštitu izvorišta voda (v. čl. 9. ZV).

84 Zabranjeno je na nasipima i drugim regulacijskim i zaštitnim vodnim građevinama: kopati i odlagati zemlju, pijesak, šljunak, jalovinu i drugi materijal, prelaziti i voziti motornim vozilima izuzev na mjestima na kojima je to izričito dopušteno, podizati nasade, obavljati druge radnje kojima se može ugroziti sigurnost ili stabilnost tih građevina; saditi drveće na udaljenosti manjoj od $10 \mathrm{~m}$ od ruba korita vodotoka ili kanala; podizati zgrade i druge objekte na udaljenosti manjoj od $10 \mathrm{~m}$ od ruba vodotoka ili kanala; u uređenom inundacijskom području orati zemlju, saditi i sjeći drveće i grmlje;u uređenom inundacijskom području: podizati zgrade, ograde i druge građevine, osim regulacijskih i zaštitnih vodnih građevina do 6 metara od vanjske nožice nasipa, odnosno od vanjskog ruba regulacijsko-zaštitne vodne građevine koja nije nasip (obala i obaloutvrda), vaditi pijesak, šljunak, kamen, glinu i ostale tvari do 20 metara od vanjske nožice nasipa, odnosno od vanjskog ruba regulacijsko-zaštitne vodne građevine koja nije nasip (obala i obaloutvrda), kopati i bušiti zdence do 20 metara od vanjske nožice nasipa, odnosno vanjskog ruba regulacijsko-zaštitne vodne građevine koja nije nasip (obala i obaloutvrda), bušiti tlo do 20 metara od vanjske nožice nasipa, odnosno od vanjskog ruba regulacijsko-zaštitne vodne građevine koja nije nasip (obala i obaloutvrda); $\mathrm{u}$ neuređenom inundacijskom području, protivno vodopravnim uvjetima: podizati zgrade, ograde i druge građevine, osim regulacijskih i zaštitnih vodnih građevina, vaditi pijesak, šljunak, kamen, glinu i ostale tvari, kopati i bušiti zdence, bušiti tlo; na građevinama za osnovnu i detaljnu melioracijsku odvodnju, do udaljenosti od $3 \mathrm{~m}$ od ruba tih građevina orati i kopati zemlju te obavljati druge radnje kojima se mogu oštetiti melioracijske vodne građevine ili poremetiti njihovo namjensko funkcioniranje; $\mathrm{u}$ vodotoke $\mathrm{i}$ druge vode, akumulacije, retencije, melioracijske i druge kanale i u inundacijskom području odlagati zemlju, kamen, otpadne i druge tvari te obavljati druge radnje kojima se može utjecati na promjenu toka, vodostaja, količine ili kakvoće vode ili otežati održavanje vodnog sustava; graditi i/ili dopuštati gradnju na zemljištu iznad natkrivenih vodotoka, osim gradnje javnih površina (prometnice, parkovi, trgovi). V. čl. 126. st. 1. ZV. 
predmetom prava vlasništva postoji niz ograničenja u radi osnovne namjene vodnog dobra da služi održavanju i poboljšanju vodnog režima.

\subsection{Raspolaganje javnim vodnim dobrom}

Mogućnosti raspolaganja javnim vodnim dobrom uređene su isključivo u $\mathrm{ZV}$-u, i javno vodno dobro u cijelosti je podvrgnuto posebnom stvarnopravnom režimu. Taj poseban stvarnopravni režim dobrim dijelom je sličan kao kod općih dobara, ali su nekretnine javnog vodnog dobra ipak u vlasničkopravnom statusu i s mogućnošću zasnivanja ograničenih stvarnih prava. Raspolaganje javnim vodnim dobrom kao predmetom stvarnog prava također je ograničeno i moguće je jedino u skladu s odredbama ZV-a.

\subsubsection{Raspolaganje pravom vlasništva na javnom vodnom dobru}

Osnovno raspolaganje stvarnim pravom podrazumijeva mogućnost prijenosa ili otuđenja tog prava na drugu osobu. ZV izrijekom propisuje da je javno vodno dobro neotuđivo, ${ }^{86}$ slijedom čega kod javnog vodnog dobra nema osnovne mogućnosti raspolaganja subjektivnim stvarnim pravom, odnosno pravo vlasništva na javnom vodnom dobru nije u prometu. ZV također propisuje da na javnom vodnom dobru ne može neka druga osoba dosjelošću niti na drugi način steći pravo vlasništva niti drugo stvarno pravo, osim prava služnosti i prava građenja na način uređen u ZV-u, te da su pravni poslovi sklopljeni suprotno tome ništetni. ${ }^{87}$ Dakle, iako je javno vodno dobro u vlasničkopravnom režimu nema mogućnosti prijenosa ili otuđenja prava vlasništva na drugu osobu, slijedom čega je u tom dijelu javno vodno dobro kao javno dobro u općoj uporabi zapravo izjednačeno s općim dobrom koje je u nevlasničkom režimu.

U odnosu na mogućnost raspolaganja vlasnika $(\mathrm{RH})$ da očitovanjem svoje volje se odrekne subjektivnog prava na javnom vodnom dobru, ZV predviđa samo mogućnost prestanka statusa javnog vodnog dobra u slučaju kad zemljišna čestica javnog vodnog dobra postane trajno nepotrebna za održavanje i poboljšanje vodnog režima ${ }^{88}$ Odluku o tome donosi nadležno ministarstvo, uz prethodno mišljenje Hrvatskih voda.$^{89} \mathrm{ZV}$ predviđa mogućnost da nositelj stvarnog prava na javnom

86 V. čl. 11. st. 5. ZV.

87 V. čl. 11. st. 6. i 7. ZV. Na javnom vodnom dobru ne može se ostvariti niti posjedovna zaštita (čl. 11 st. $8 . \mathrm{ZV}$ ).

88 V. čl. 12. st. $1 . \mathrm{ZV}$.

89 Rješenje ministarstva sadrži oznaku nekretnine koja je izgubila status javnog vodnog dobra i nalog sudu za otpis ove zemljišne čestice i pripis u novi zemljišnoknjižni uložak, s upisom prava vlasništva RH uz istodobno brisanje tereta zabrane otuđenja i opterećenja nekretnine založnim pravom i posljedice ništetnosti pravnih poslova. Rješenje Ministarstva je konačno i ovršno. Rješenje se dostavlja nadležnom državnom odvjetništvu, protiv njega se može pokrenuti upravni spor, a na konačno rješenje ministarstvo stavlja potvrdu ovršnosti i dostavlja ga nadležnom zemljišnoknjižnom sudu, koji će ga provesti po službenoj 
vodnom dobru $(\mathrm{RH})$ to svoje pravo optereti pravom služnosti i pravom građenja kao ograničenim stvarnim pravima. ${ }^{90}$ Pretpostavke zasnivanja prava služnosti i prava građenja u korist pravnih i fizičkih osoba su da je to radi ostvarenja gospodarskih ili osobnih potreba, da se radi o dijelu javnog vodnog dobra i da zasnivanje navedenih ograničenih stvarnih prava ne utječe na ostvarivanje namjena iz čl. 9. ZV-a, o čemu mišljenje daju Hrvatske vode. ${ }^{91} \mathrm{O}$ davanju prava služnosti i prava građenja odlučuje Vlada RH, ili od nje ovlašteno tijelo, a ugovore kojim se zasniva pravo služnosti ili pravo građenja također $\mathrm{u}$ ime RH sklapa Vlada RH ili od nje ovlašteno tijelo. ${ }^{92}$

\subsubsection{Raspolaganje javnim vodnim dobrom kao predmetom stvarnog prava}

ZV propisuje i moguće načina raspolaganja javnim vodnim dobrom kao predmetom stvarnog prava (prava vlasništva). Sadržaj izvršavanja ove vlasnikove ovlasti također je ograničen kod javnog vodnog dobra na mogućnost davanja dijela javnog dobra u najam ili zakup te iznimno na gradnju građevina na javnom vodnom dobru koje su u vlasništvu RH ili u statusu općeg dobra. ${ }^{93}$ Pretpostavke davanja dijela javnog vodnog dobra u najam ili zakup su iste kao kod zasnivanja prava služnosti i prava građenja, a o davanju dijela javnog vodnog dobra u najam i zakup kao i o visini naknade za ta prava odlučuje također Vlada RH. ${ }^{94}$ Razlika je u ovlašteniku za sklapanje ugovora u ime RH, jer ugovore o najmu i zakupu javnog vodnog dobra sklapaju Hrvatske vode u ime RH, a prihod od naknade po toj osnovi je prihod Hrvatskih voda. ${ }^{95}$ Poseban način raspolaganja javnim vodnim dobrom dopuštenje je izgradnje građevine u vlasništvu RH ili koja je u statusu općeg dobra, a čiji je investitor ili RH ili pravne osobe u kojima je RH većinski udjeličar, dioničar ili osnivač s većinskim pravom odlučivanja, o čemu odluku donosi Vlada RH. ${ }^{96}$

dužnosti. Upis javnog vodnog dobra u zemljišnu knjigu propisan je odredbama $Z V$-a, te se $u$ posjedovnicu (list A), uz podatke koji se inače upisuju u posjedovnicu, upisuje i oznaka vrste javnog vodnog dobra iz čl. 8. ZV-a, u vlastovnicu (list B) upisuje se naznaka ,javno vodno dobro u općoj uporabi u vlasništvu RH“ i naznaka pravne osobe koja upravlja tim dobrom, a u teretovnicu (list C) upisuje se zabrana otuđenja i zabrana opterećenja nekretnine založnim pravom, uz naznaku posljedice ništetnosti pravnih poslova.

90 V. čl. 16. st. 1. ZV.

91 Ibid.

92 V. čl. 16. st. 3. i 6. ZV. Visinu naknade za pravo služnosti i pravo građenja propisuje Vlada $\mathrm{RH}$, a prihod po toj osnovi je prihod državnoga proračuna.

93 V. čl. 16. st. 1. i 3. ZV. Tu se ne radi o zasnivanju prava građenja u korist drugih pravnih i fizičkih osoba, već o gradnji građevina same RH kao vlasnika ili građevina u pravnom statusu općeg dobra. Potpuno je nejasno što je zakonodavac podrazumijevao pod gradnjom građevina u pravnom statusu općeg dobra, odnosno nemoguće je na zemljištu koje je u vlasničkopravnom statusu imati građevinu u pravnom statusu općeg dobra. U pravnom sustavu RH samo nekretnine pomorskog dobra su u pravnom statusu opéeg dobra (v. čl. 3. Zakona o pomorskom dobru i morskim lukama, Narodne novine, broj 158/03, 100/04, 141/06, 38/09 i 123/11 - dalje u tekstu ZPDML).

94 V. supra bilj. 90., 91. i 92.

95 V. čl. 16. st. 3. i 8. ZV.

96 V. čl. 16. st. 4. ZV. 


\section{ZAKLJUČAK}

Mogućnosti raspolaganja vodnim dobrom ovise o tome tko je vlasnik zemljišnih čestica koje čine vodno dobro. Ako je RH vlasnik te posebne vrste nekretnina koje služe održavanju i poboljšanju vodnog režima, tada je mogućnost raspolaganja vodnim dobrom znatno ograničena, $i$ to posebno $u$ odnosu na raspolaganje pravom vlasništva kao subjektivnim pravom. Samom činjenicom da je vlasnik vodnog dobra RH, takve nekretnine prelaze u pravni status javnog dobra u općoj uporabi i podvrgnute su ograničenjima koja za tu vrstu javnog dobra u općoj uporabi propisuje $\mathrm{ZV}$.

Vodno dobro je dobro od interesa za RH, te je osnovno ograničenje u raspolaganju pravom vlasništva fizičkih i pravnih osoba u pravu prvokupa $\mathrm{RH}$ u slučaju namjere prijenosa ili otuđenja prava vlasništva prodajom nekretnine vodnog dobra. Kod drugih raspolaganja pravom vlasništva na vodnom dobru nema razlike $\mathrm{u}$ raspolaganju u odnosu na bilo koju drugu nekretninu u običnom stvarnopravnom režimu. Kod raspolaganja vodnim dobrom kao predmetom stvarnog prava, ZV je propisao niz ograničenja koja se svode na to da su vlasnici vodnog dobra ograničeni u vršenje sadržaja svog subjektivnog prava u svrhu održavanja i poboljšanja vodnog režima.

Otuđenje ili prijenos prava vlasništva kod javnog vodnog dobra nije moguće, te je javno vodno dobro zapravo izvan prometa. Izrijekom je isključena mogućnost stjecanja prava vlasništva dosjelošću ili na bilo koji drugi način te nema mogućnosti stjecanja posjeda drugih osoba. Moguće je jedino zasnivanje prava služnosti i prava građenja kao ograničenih stvarnih prava, ali samo uz uvjete i u postupku propisanom u ZV-a. Nije moguće niti očitovanje volje vlasnika javnog vodnog dobra u smislu odreknuća subjektivnog prava na javnom vodnom dobru, već ZV propisuje mogućnost prestanka pravnog statusa javnog vodnog dobra u slučaju kad zemljišne čestice javnog vodnog dobra postanu trajno nepotrebne za održavanje i poboljšanje vodnog režima. Raspolaganje javnim vodnim dobrom kao predmetom stvarnog prava moguće je davanjem dijela javnog vodnog dobra u najam ili zakup, odnosno iznimno u svrhu gradnje građevina koje su u vlasništvu RH ili su u pravnom statusu općeg dobra, a čiji je investitor RH ili pravne osobe u kojima je RH većinski udjeličar, dioničar ili osnivač s većinskim pravom odlučivanja. 


\section{Summary}

\section{DISPOSING OF WATER RESOURCES}

This paper discusses the possibilities of disposing of water resources as a resource that is of interest to the Republic of Croatia from the aspect of disposing of the right of ownership as a property right and of disposing of the subject matter of property law. It also makes a distinction between disposing of water resources on the one hand and disposing of public water resources as public property for common usage on the other hand. The concept, definition and legal status of water resources are presented in the introduction, as the basis for an analysis of the possibility of disposing of, or limiting the disposal of, water resources. Further, an analysis is made of the basic characteristics of disposing of property rights in general, and of disposing of resources that are of interest to the Republic of Croatia and public property for common usage.

Keywords: water resources, public water resources, resources of interest to the Republic of Croatia, public property for common usage.

\section{Zusammenfassung}

\section{DIE VERFÜGUNG ÜBER WASSERGUT}

Diese Arbeit berücksichtigt die Möglichkeiten einer Verfügung über Wassergüter als Güter vom Interesse für die Republik Kroatien aus der Sicht der Verfügung über Eigentumsrecht als Sachenrecht und gleichzeitig als Gegenstand des Sachenrechts. Dabei wird die Verfügung über Wassergüter als öffentliche Güter in allgemeinem Gebrauch dargestellt. Nach einer näheren Bestimmung des Begriffs und Rechtsstatus des Wassergutes werden die Verfügungsmöglichkeiten und Begrenzungen, wie auch Grundmerkmale der Verwaltung von Sachenrechten; von Gütern im Interesse der Republik Kroatien und öffentlichen Gütern im allgemeinen Gebrauch unter die Lupe genommen.

Schlüsselwörter: Wassergut, öffentliches Wassergut, Güter vom Interesse für die Republik Kroatien, öffentliche Güter im allgemeinen Gebrauch. 


\section{Riassunto}

\section{DISPONIBILITÀ DEL DEMANIO IDRICO}

Nel lavoro si vagliano le possibilità di disporre del demanio idrico, quale bene d'interesse per la Repubblica di Croazia sotto il profilo della disponibilità del diritto di proprietà come diritto reale e della disponibilità del contenuto della titolarità del diritto reale medesimo. Al contempo si distingue l'analisi della disponibilità del demanio idrico dalla disponibilità del demanio idrico pubblico, quale demanio pubblico di utilizzo comune. Inizialmente si indica la nozione, la definizione e lo status giuridico del demanio idrico quale fondamento dell'analisi circa la possibilità di disporre o di porre limitazioni alla disponibilità del demanio idrico; come pure s'individuano le caratteristiche di base della disponibilità dei diritti reali in generale e della disponibilità dei beni di interesse per la Repubblica di Croazia, come anche dei beni pubblici di utilizzo comune.

Parole chiave: demanio idrico, demanio idrico pubblico, beni di interesse per la Repubblica di Croazia, beni pubblici di utilizzo comune. 